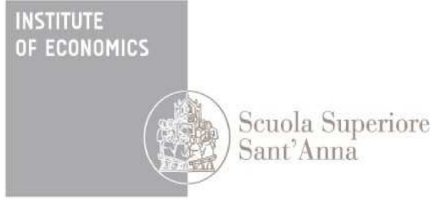

LEM | Laboratory of Economics and Management

Institute of Economics

Scuola Superiore Sant'Anna

Piazza Martiri della Libertà, 33 - 56127 Pisa, Italy ph. +3905088.33 .43$

institute.economics@sssup.it

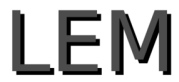

Working Paper Series

Productivity and structural heterogeneity in the Brazilian manufacturing sector: trends and determinants

\author{
Eva Yamila Catela ${ }^{a}$ \\ Mario Cimoli ${ }^{b}$ \\ Gabriel Porcile ${ }^{c}$ \\ ${ }^{a}$ Department of Economics, Federal University of Santa Catarina \\ ${ }^{b}$ ECLAC and Department of Economics, University of Venice \\ ${ }^{c}$ ECLAC and Department of Economics, Federal University of Parana
}




\title{
Productivity and structural heterogeneity in the Brazilian manufacturing sector: trends and determinants \#
}

\author{
Eva Yamila Catela ${ }^{\mathrm{a}}$, Mario Cimoli ${ }^{\mathrm{b}}$, Gabriel Porcile ${ }^{\mathrm{c}}$ \\ ${ }^{a}$ Department of Economics, Federal University of Santa Catarina (UFSC) \\ ${ }^{\mathrm{b}}$ ECLAC and Department of Economics, University of Venice \\ ${ }^{c}$ ECLAC and Department of Economics, Federal University of Parana (UFPR)
}

\begin{abstract}
This paper discusses the evolution of firms' productivity and structural heterogeneity (SH) in the Brazilian manufacturing industry in the 2000s. SH is defined (following the Latin American structuralist tradition) as a situation in which a large share of total firms is in the lowest productivity groups of the production structure, and there are very large differences in labour productivity between groups and firms. The paper combines and makes compatible several databases on manufacturing production, innovation and microsocial data for Brazil, in order to measure productivity and $\mathrm{SH}$, to analyze its evolution between 2000 and 2008, and to discuss its determinants. Econometric analyses (k-means cluster methodology to identify productivity groups, and ordered probit models to analyse the determinants of $\mathrm{SH}$ ) show that increasing returns in innovation and learning prevailed in the 2000s, while policies failed to encourage the catching up process by laggard firms. As a result, $\mathrm{SH}$ did not fall in the Brazilian manufacturing sector.
\end{abstract}

Key words: Structural heterogeneity; technological change; productivity growth; technological asymmetries.

JEL Classification: L22, L25, O33, O31

\# Acknowledgment. The authors are very grateful to the Instituto de Pesquisa Econômica Aplicada (Institute of Applied Economic Research, IPEA) of the Brazilian Federal Government, whose generous support made this research possible. Usual disclaimers apply. 


\section{Introduction}

The acceleration of productivity growth and its diffusion to the whole economy is central to the process of development. Developing economies generally comprise a few enclaves of very high productivity, while most firms and employment remains in sectors or activities of very low productivity. To deal with this specific feature of developing economies, the concept of structural heterogeneity $(\mathrm{SH})$ was originally formulated by authors related to the Economic Commission for Latin America and the Caribbean (ECLAC), in the context of the centre-periphery theory ${ }^{1}$ (see Pinto, 1970, 1976; Sunkel, 1978; Rodríguez, 2007; Infante and Sunkel, 2009). These authors argue that barriers to the diffusion of technology exist not only at the international level, but also at the domestic level. Technology diffuses very slowly within developing economies (periphery) and as a result the share of total firms and employment in low-productivity sectors remains very high, while differences in productivity between firms (in the same or in different sectors) do not fall. ECLAC designated this feature of the production structure of the periphery as "structural heterogeneity" ( $\mathrm{SH})$. Clearly, productivity differences are inherent to capitalist competition and constantly emerge out of different rates of technical change across sectors and firms (Dosi et al, 2010). The very objective of the competition process is to create asymmetries and oligopoly profits. However, asymmetries tend to be more acute and persistent in peripheral countries, where technical progress is concentrated in few sectors and within them, in a few firms, contributing to heighten inequality - a striking feature of the Latin American countries in general and of Brazil in particular (ECLAC, 2010, 2012; Cimoli and Rovira, 2010)².

\footnotetext{
1 The seminal work on centre-periphery theory is Prebisch $(1950 ; 1952)$. This theory points out that there are significant asymmetries in technological capabilities across countries that explain why economic structures are so different and how they affect long run growth and divergence. There is a group of countries - the centre-whose economy is diversified and close to the technological frontier. Within this group, forward and backward linkages are strong, while the catching up process with the technological leader occurs rapidly. Inversely, in another group of countries-the periphery-the diffusion of technology is slow and irregular, giving rise to an economic structure highly specialized in few low-tech commodities.

2 Income inequality depends on a broader set of variables, particularly on the tax system and the redistributive effects of public expenditure. But a very high initial level of inequality in productivity and
} 
Development consists to a large extent in reducing SH by moving firms and workers from low-productivity sectors / activities to high-productivity sectors / activities (Cimoli and Porcile, 2011; McMillan and Rodrik, 2011). The focus of this paper is on the migration of firms in the Brazilian manufacturing industry from low-productivity groups to higher-productivity groups, and on the variables that explain the probability of such a migration. We first identify groups or strata of firms in which productivity is markedly different using a cluster k-means methodology. SH is measured through the share of total firms in the lowest productivity groups and the productivity gap between groups. We then discuss whether $\mathrm{SH}$ is a persistent phenomenon or decreases through time. Subsequently, using an ordered probit model, we analyze the determinants of the probability with which firms migrate from low productivity groups towards high productivity groups, or remain trapped in low productivity groups. The influence of a set of explanatory variables on this probability is tested. To perform these tests, we combine microdata from different sources on the Brazilian manufacturing industry, namely the Annual Industrial Survey (PIA), the Survey on Technological Innovation (PINTEC), and the Annual Social Information Report (RAIS). These databases, which comprise data collected at the firmlevel, are for the first time combined to study the evolution of productivity and SH.

The paper is in four sections besides this introduction and the concluding remarks. Section 2 discusses the concept of SH and its relation with technological and structural change, providing the analytical framework for the empirical sections. It also briefly presents the methodology of analysis. Section 3 presents the evolution of SH and discusses the results of the ordered probit model as regards the determinants of firms' migration between groups.

\section{Structural Heterogeneity}

\subsection{Structural heterogeneity and technical change}

The concept of structural heterogeneity describes a specific feature of the production structure of the developing economies (periphery) in contrast to taht of the developed

labor income makes more challenging the redistributive process, particularly in economies in which political power is by large in the hands of the richest. 
economies (centre). The economic structure of the centre is diversified and homogeneous: diversified because there is a wide range of strongly interrelated sectors, and homogeneous because differences in labour productivity across firms and sectors are relatively small. On the other hand, the production structure of the periphery is specialized in few sectors (mostly based on natural resources or cheap labour) and heterogeneous, since differences in labour productivity tend to be higher than in the centre (ECLAC, 2010). These asymmetries are related to differences in the diffusion of technical progress and the capital intensity of production, as well as to the existence of a large surplus of labour in the subsistence sector of the developing economy (Furtado, 1969, 1972).

Figure 1 illustrates this view in a highly stylized form. The figure on the right represents the centre, and the one on the left the periphery. In the horizontal axis there is a sequence of numbers $\mathrm{N}=1,2,3 \ldots \mathrm{N}^{\mathrm{i}}$ which represent economic sectors, ranked in descending order according to labor productivity. Sector 1 is the one with the highest productivity, while the last sector (denoted as $\mathrm{N}^{\mathrm{C}}$ or $\mathrm{N}^{\mathrm{P}}$, where $\mathrm{C}$ and $\mathrm{P}$ indicate centre and periphery) holds the lowest productivity level. The economic structure of the centre is more diversified and hence the total number of sectors is greater than in the periphery $\left(\mathrm{N}^{\mathrm{C}}>\right.$ $\mathrm{N}^{\mathrm{P}}$ ). Since each number corresponds to a sector in a ranking of decreasing productivity, they do not necessarily represent the same sector in centre and the periphery. The $\mathrm{N}=1$ sector in the periphery (highest productivity) is most likely to be intensive in natural resources, whereas in the centre the sector $\mathrm{N}=1$ is most likely to be intensive in technology or capital. 
Center

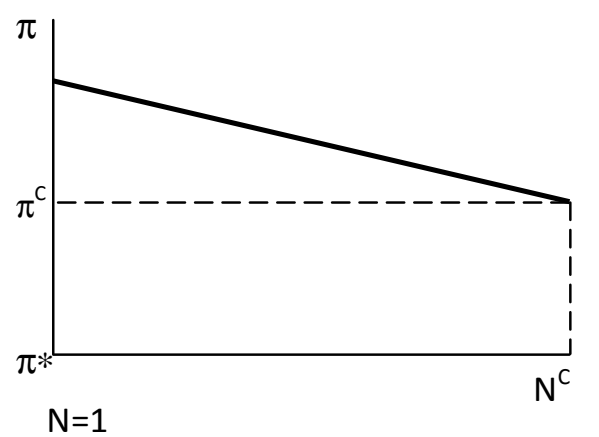

Periphery

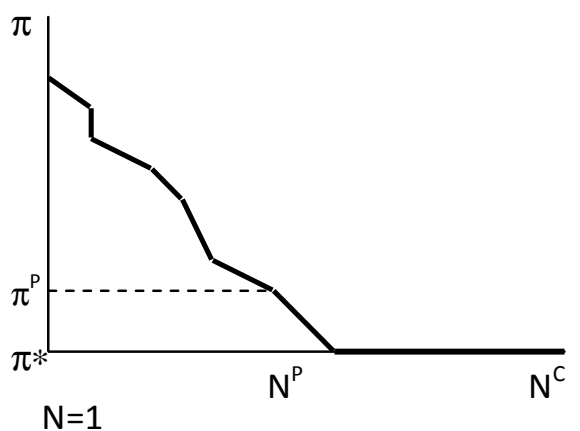

$\pi=$ Labour Productivity.

$\mathrm{N}=$ Number of economic sectors ordered in descending order according to labour productivity

$\mathrm{N}^{\mathrm{C}}=$ Total number of sectors in the centre

$\mathrm{N}^{\mathrm{P}}=$ Total number of sectors in the periphery .

$\pi^{*}=$ Labour productivity in the subsistence sector of the periphery .

$\pi^{\mathrm{C}}=$ Labour productivity in the last sector of the centre (number $\mathrm{N}^{\mathrm{C}}$ ).

$\pi^{\mathrm{P}}=$ Labour productivity in the last sector of the periphery (number $\mathrm{N}^{\mathrm{P}}$ ).

Labor productivity $(\pi)$ appears on the $y$-axis, whose value at the point of origin is $\pi *$ which is the labor productivity of the subsistence sector in the periphery. For simplicity it is assumed that in the centre the productivity curve declines at a constant rate as it moves smoothly from one sector to another, and there are no "steps" within the modern sector. On the contrary, in the periphery productivity falls with a very steep gradient and there are marked steps between sectors.

The process of economic development requires transforming the productivity curve so as to reduce its slope, eliminate steps and draw the labour surplus out of the subsistence sector. This in turn implies fostering the migration of firms from low-productivity activities to higher productivity activities. To understand the forces leading to the upgrading in productivity and the production structure, it is necessary to briefly recall the 
determinants of technological diffusion in developing economies-the microeconomics of learning in a centre-periphery setting.

Technological capabilities are the basis for sustaining competitiveness and growth. At least since the beginning of 1970s, it has been recognized that catching up economies relies on mastering, adapting and improving the advanced technology of the countries on the technological frontier (Katz, 1987; Dosi et al, 1990). But this is a complex task, as innovation and diffusion of technology are characterized by rigidities and pathdependency. There exists "stickiness in capabilities", meaning that the technological and production systems do not respond in a flexible way to changes in market signals. A first approach to this problem is the classical argument by Atkinson and Stiglitz (1969) suggesting that the isoquants should be seen as "points" in the plane, and that learning is strongly localized around existing technologies-in other words, firms produce new knowledge just within a small interval of feasible technologies concentrated in the vicinity of the technology they are actually using.

Since the mid-seventies, the Schumpeterian evolutionary literature has provided strong theoretical and empirical basis to the idea that the expansion or contraction of the productive and technological capabilities is not a linear, reversible process (Dosi, 1988; Cimoli and Dosi, 1995; Cimoli and Porcile, 2009). Technological learning features a set of inter-related regularities that cannot be ignored, namely:

i) It is subject to path-dependence, i.e. the evolution of capabilities depends on previous experience and directions of past learning;

ii) In many cases learning is tacit: it cannot be codified nor diffused trough manuals or formal instructions, and therefore requires actual experience in producing and using new technology;

iii) There exists complementary between sectors and capabilities, in such a way that externalities and increasing returns are crucial at both the industrial and economy levels;

iv) There is irreversibility in the accumulation of certain (physical and 
technological) assets, which cannot just be abandoned or replaced;

v) There are significant differences across sectors in terms of technological opportunities and trajectories of productivity growth. Therefore, the relative rates of innovation and diffusion of technology, learning and selection of firms and market concentration may vary significantly across sectors;

vi) One of the important factors for technology diffusion is human capital and the construction of an appropriate institutional environment for learning, in particular the industrial and technological policies (Freeman, 1995; Metcalfe, 2001). The role of human capital has also been emphasized in the endogenous growth models (Grossman and Helpman, 1991, Aghion and Howitt, 1997), where the number of researchers undertaking $R \& D$ plays a central role in explaining productivity increases in the firm.

The combination of these forces in the dynamics of learning suggests strong cumulativeness, which implies that-in a context of high initial technological asymmetries-countries and firms that are closer to the technological frontier will increase their advantage with respect to the laggards. The endogenous forces of learning (path dependence and increasing returns) reproduce and amplify technological leads and lags - what can be seen as the microdynamics that supports the macrodynamics of divergence of the centre-periphery theory. In order to avoid the rapid concentration of the market in few firms and the persistence of an enclave structure, the role of industrial policy and public support for catching up is crucial (Freeman, 1995; Metcalf, 2001). Policies aimed at the construction of an institutional framework conducive to technological diffusion and catching up may allow the laggards to learn before being ousted of the market. The need of policies to reduce $\mathrm{SH}$ is higher when the forces of increasing returns are stronger.

\subsection{Measuring structural heterogeneity: questions and methodology}

From an empirical point of view, three questions arise. The first question is how many productivity groups exist in the industry. In other words, it is necessary to determine the 
slope of the productivity curve, the size of the productivity steps (as illustrated in Figure 1), and the share of total firms in the lowest productivity group. This amounts to an indicator of SH. The second question is how the productivity curve evolves in time and which variables determine this evolution. The third question is related to the role of public policy in reducing $\mathrm{SH}$, i.e., whether this policy may play an effective role in reducing the skewness of the distribution of firms' productivity.

To respond these questions, we firstly identify groups or strata of different levels of labour productivity following a statistical procedure, namely the cluster-k means methodology (subsection 3.1; see also Appendix 1). Secondly, the probability that a firm migrates between groups or strata is tested in a model comprising the various explanatory variables of the dynamics of learning presented above (subsection 3.2). The data used in the empirical exercises refers to the $2000-2008^{3}$ period and is based on the combination of four large databases of the Brazilian manufacturing industry: a) the Annual List of Social Information (RAIS) of the Ministry of Labour and Employment (MTE); b) the Secretariat of Foreign Trade (Secex) of the Ministry of Development, Industry and Foreign Trade; c) the Annual Industrial Survey (PIA) of the Brazilian Institute of Geography and Statistics (IBGE); and d) the Survey of Innovation and Technology (PINTEC) of the Brazilian Institute of Geography and Statistics (IBGE). Crossing these different databases produces a sample containing information for approximately 4,000 firms with 30 workers or more. Smaller firms (with less than 30 employees) are not included in the survey because their data come from random sampling, not from censuses.

The cluster analysis permits to form homogeneous groups within a population of heterogeneous components, based on univariate or multivariate data. An optimal number of groups is formed out of the total sample of Brazilian manufacturing firms. The variables considered in the analysis are average productivity, the standard deviation of productivity and the number of firms that belong to each group. Their evolution in time, particularly the migration of firms between groups, is also taken into account.

3 This is the last year for which there is available data. 
After the identification of the optimal number of productivity groups, the effects of a set of explanatory variables on the probability that a firm migrates to a group of higher productivity level are estimated. The explanatory variables are those discussed in the previous section: increasing returns (both static and dynamic); disembodied technical change (learning by doing and learning by exporting); firms' initial capabilities and efforts at innovation or imitation of technology; and policies that encourages technological diffusion across firms. Subsequently, a similar exercise is performed considering the sector to which the firm belongs (since there are sector-specific factors affecting the dynamics of innovation and diffusion between heterogeneous firms).

\section{SH in the Brazilian manufacturing industry: an empirical study}

\subsection{Grouping of firms.}

$\mathrm{SH}$ is defined by two dimensions, the percentage of total firms in low productivity groups, and the productivity gap (the "size of the step") that exists between firms belonging to different productivity groups. This section discusses the evolution of these dimensions between 2000 and 2008. It is shown that SH did not decline in this period, since there was an increase in both the share of firms in the low productivity groups and in the productivity gap.

The k-cluster methodology indicates that firms in the Brazilian manufacturing industry can be optimally grouped into five categories. Table 1 presents the results of this grouping for 2000, 2004 and 2008. Comparing the percentage of total firms in each group in 2000 and 2008, it can be observed an increasing share of firms in group 1 (very low productivity), group 4 (medium-high productivity) and group 5 (high productivity) is observed. Inversely, the two intermediate groups (low productivity and medium productivity) reduce their share in the total number of firms in the same period. There is therefore a rise in the percentage of firms in the polar groups: the group of low productivity increased its share by two percentage points, going from $12.50 \%$ to $14.60 \%$, while the groups of higher productivity (4 and 5) increased from $30.20 \%$ to $33.20 \%$ between 2000 and 2008 . 
Table 1- Productivity groups according with the k-cluster means methodology

\begin{tabular}{|c|c|c|c|}
\hline Year & Cluster & $\begin{array}{r}\text { Percentages } \\
(\%)\end{array}$ & Average Productivity (R\$) \\
\hline 2000 & 1 & 12,53 & 10038 \\
\hline 2000 & 2 & 26,32 & 34966 \\
\hline 2000 & 3 & 30,95 & 94524 \\
\hline 2000 & 4 & 22,50 & 254104 \\
\hline 2000 & 5 & 7,70 & 988901 \\
\hline 2004 & 1 & 15,50 & 9314 \\
\hline 2004 & 2 & 24,98 & 29979 \\
\hline 2004 & 3 & 28,69 & 95121 \\
\hline 2004 & 4 & 23,11 & 274057 \\
\hline 2004 & 5 & 7,73 & 1185529 \\
\hline 2008 & 1 & 14,59 & 9424 \\
\hline 2008 & 2 & 25,54 & 30374 \\
\hline 2008 & 3 & 26,69 & 89760 \\
\hline 2008 & 4 & 24,45 & 251687 \\
\hline 2008 & 5 & 8,73 & 1031258 \\
\hline
\end{tabular}

Source: Prepared on the basis of PINTEC data.

The analysis of average productivity per group leads to a similar conclusion. Firstly, comparing the results for the first year (2000) with those of the intermediate year (2004), there is a decline of labour productivity in groups 1 and 2; stagnation in the average level of productivity in group 3; and a marked increase in productivity in the groups of higher productivity (4 and 5). Secondly, comparing the first year (2000) with the last year (2008), the average productivity of all clusters decreased, with the exception of group 4, that kept the same average productivity level of the 2000 (although there is a fall in productivity between 2004 and 2008). 
In sum, the low productivity group did not reduce their share, while the productivity gap tended to increase. There was a process of polarization, suggesting that the forces of divergence tended to prevail in the period under analysis.

Figure 2 - Relative Productivity of groups 1-4 compared to group 5: 2000-2008

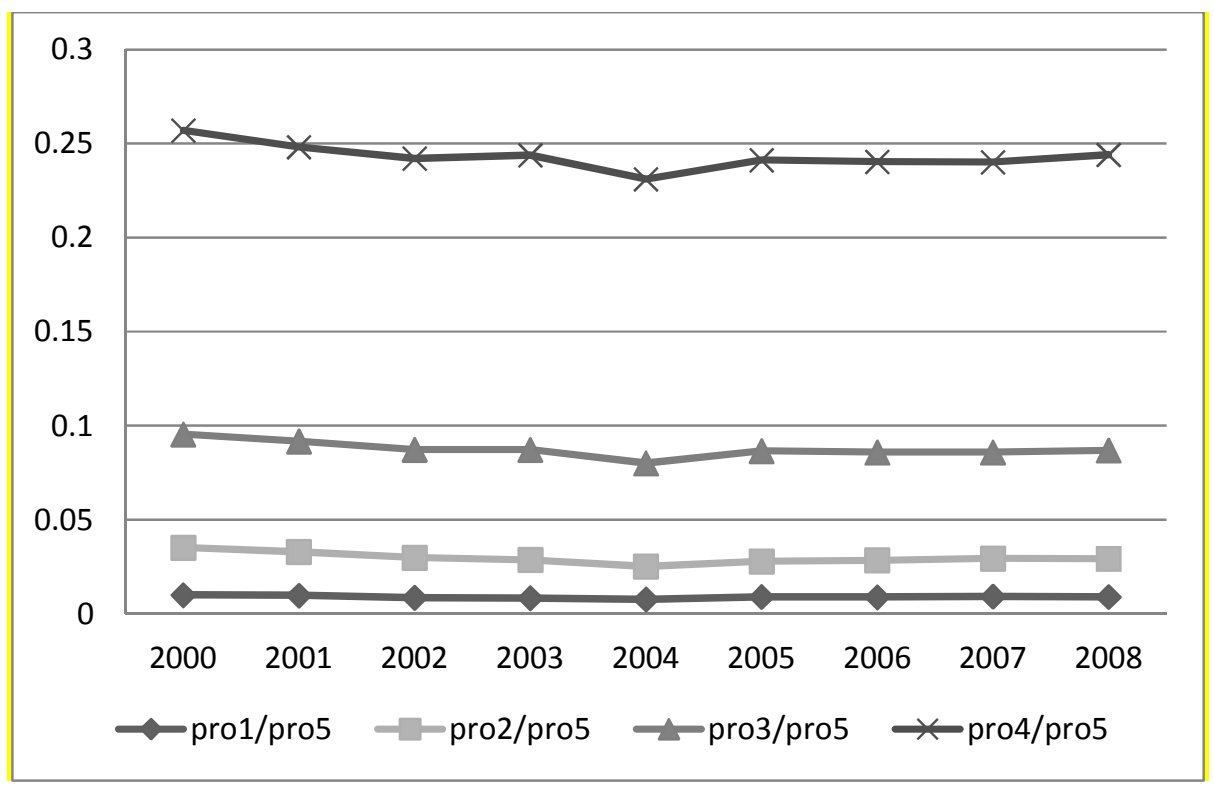

Source: Prepared on the basis of PINTEC and PIA data.

Figure 2 shows that the relative productivity of the different groups with respect to group 5 (the group with the highest productivity) decreased or remained constant through time. The fall in relative productivity was more visible between 2000 and 20004, and only partially reverted thereafter.

3.2. An ordered probit model: the critical role of initial capabilities and dynamic increasing returns

From the analysis of section I we expect that a firm is more likely to stay or migrate towards a higher productivity group when invests more in physical and human capital; counts on a larger experience in production and innovation; has a larger scale of production; benefits from technological spillovers stemming from trade and imports of capital goods; and relies on a set of institutions and policies that foster technological 
diffusion. These are key determinants of innovation and technological diffusion that will be tested in the probit model of section 4. All these forces boost polarization-and are compatible with the persistence of $\mathrm{SH}$, as mentioned. They might be compensated by active public policies aimed at facilitating technological diffusion and catching up by laggards and smaller firms.

In the probit model, the dependent variable corresponds to the five groups of firms ranked from 1 to 5 in terms of (increasing) productivity, described in the previous section. The proxies for the explanatory variables used in the econometric tests are the following (see also Appendix 2.1):

a) Innovation capabilities in the firm, measured through three indicators: (i) product innovation in the firm (innovate); (ii) workers' education, measured by the average years of schooling (study time); (iv) number of innovative employees in the firms, such as engineers, scientists, and researchers (in_wf);

b) Cumulative (tacit) learning, for which two proxies are used: (i) years of fulltime employment in the labor market, in the same or different firms (leaning by doing); (ii) years of employment in the same firm (length_emp). These two variables reflect the impact of experience and tacit knowledge on the accumulation of capabilities. They are based on the information provided by RAIS (2005);

c) Learning by exporting, captured by share of exports in the total sales of the firm. Exports contribute to boost learning, as international markets tend to be more demanding in terms of quality and productivity. Moreover, competition is usually stronger in these markets. In addition, the evidence suggests that industries that offer high technological opportunities and high productivity growth also attain higher rates of growth in exports (Montobbio and Rampa, 2005);

d) Economies of scale, measured by the firm's share in the total revenue of its sector (share income) and by the number of employees (contracts); 
e) Policy Variables. Innovation is a systemic process and institutional factors are critical for its success, particularly public support and finance. Based on PINTEC data, two proxies were used to capture the institutional dimension: (i) direct public funding for $R \& D$ and technological innovation (with or without partnership whit universities and research institutes), and public funding for the purchase of machinery and equipment used in innovation (public_fin); (ii) indirect government assistance, comprising fiscal incentives to $\mathrm{R} \& \mathrm{D}$ and technological innovation, tax incentives of the Law of Informatics, subsidies for R\&D spending and the hiring of researchers, grants to researchers working in firms, and the provision of venture capital (public_sup; see Appendix 2.1). It is expected that this set of policy variables may contribute to accelerate the diffusion of technology to laggard firms and hence reduce $\mathrm{SH}$.

The results of the econometric exercise with the oredered probit model are presented in Table 2: the marginal effect of the whole sample is in the first column, and the marginal effects for each of the productivity groups are in the next five columns. Marginal probabilities are calculated based on the average firm of the sample, which implies that the explanatory variable takes the average value of the group. 
Table 2 - Results of the Ordered Probit Model: General and marginal effects (EMG)

\begin{tabular}{|c|c|c|c|c|c|c|}
\hline Variable & General & EMgclu1 & EMgclu2 & EMgclu3 & EMgclu4 & EMgclu5 \\
\hline \multirow[t]{2}{*}{ Contract } & 0,0001 & $-0,0001$ & $-0,0001$ & $-0,0001$ & 0,0001 & 0,0001 \\
\hline & $(0,0000)$ & $(0,0000)$ & $(0,0000)$ & $(0,0000)$ & $(0,0000)$ & $(0,0000)$ \\
\hline \multirow[t]{2}{*}{ share_income } & 21,9692 & $-1,5222$ & $-3,8992$ & $-3,3379$ & 5,1642 & 3,5951 \\
\hline & $(1,9166)$ & $(0,1378)$ & $(0,3432)$ & $(0,2970)$ & $(0,4562)$ & $(0,3158)$ \\
\hline \multirow{2}{*}{$\begin{array}{l}\text { learning by } \\
\text { exporting }\end{array}$} & 0,5902 & $-0,0389$ & $-0,1002$ & $-0,0930$ & 0,1284 & 0,1036 \\
\hline & $(0,0144)$ & $(0,0013)$ & $(0,0026)$ & $(0,0027)$ & $(0,0033)$ & $(0,0029)$ \\
\hline \multirow[t]{2}{*}{ Innovate } & 0,2821 & $-0,0198$ & $-0,0500$ & $-0,0422$ & 0,0660 & 0,0461 \\
\hline & $(0,0246)$ & $(0,0018)$ & $(0,0044)$ & $(0,0037)$ & $(0,0058)$ & $(0,0041)$ \\
\hline \multirow[t]{2}{*}{ in_wf } & 0,0018 & $-0,0001$ & $-0,0003$ & $-0,0003$ & 0,0004 & 0,0003 \\
\hline & $(0,0004)$ & $(0,0000)$ & $(0,0001)$ & $(0,0001)$ & $(0,0001)$ & $(0,0000)$ \\
\hline \multirow[t]{2}{*}{ study_time } & $\mathbf{0 , 3 3 8 9}$ & $-0,0234$ & $-0,0602$ & $-0,0515$ & 0,0797 & 0,0555 \\
\hline & $(0,0051)$ & $(0,0006)$ & $(0,0012)$ & $(0,0012)$ & 0,0016 & $(0,0011)$ \\
\hline \multirow[t]{2}{*}{ length_emp } & 0,0052 & $-0,0004$ & $-0,0010$ & $-0,0008$ & 0,0012 & 0,0009 \\
\hline & $(0,0003)$ & $(0,0000)$ & $(0,0001)$ & $(0,0001)$ & $(0,0001)$ & $(0,0001)$ \\
\hline \multirow{2}{*}{$\begin{array}{l}\text { learning by } \\
\text { doing }\end{array}$} & 0,0607 & $-0,0042$ & $-0,0108$ & $-0,0092$ & 0,0143 & 0,0099 \\
\hline & $(0,0022)$ & $(0,0002)$ & $(0,0004)$ & $(0,0004)$ & $(0,0006)$ & $(0,0004)$ \\
\hline \multirow[t]{2}{*}{ public_sup } & 0,0708 & $-0,0050$ & $-0,0126$ & $-0,0106$ & 0,0167 & 0,0115 \\
\hline & $(0,0243)$ & $(0,0017)$ & $(0,0044)$ & $(0,0036)$ & $(0,0058)$ & $(0,0039)$ \\
\hline \multirow[t]{2}{*}{ public_fin } & $-0,0608$ & 0,0049 & 0,0122 & 0,0098 & $-0,0163$ & $-0,0107$ \\
\hline & $(\mathbf{0 , 0 3 1 3 )}$ & $(0,0024)$ & $(0,0058)$ & $(0,0043)$ & $(0,0077)$ & $(0,0048)$ \\
\hline Observations & 26619 & $8,08 \%$ & $13,28 \%$ & $35,01 \%$ & $34,54 \%$ & $9,09 \%$ \\
\hline LR chi & 11997,94 & & & & & \\
\hline
\end{tabular}

Source: Prepared on the basis of PINTEC, PIA, SECEX and RAIS data. See Appendix2.1 for the key to the variables. 
The main results presented in Table 2 can be summarized as follows.

Firstly, economies of scale, measured by the firm's share in the sector total revenue (share income), raise the probability of migration towards a group with higher productivity. The negative marginal effect in the first three groups means that a $1 \%$ increase in the revenue share variable is associated with a decrease in the probability of remaining in groups 1, 2 and 3 (of 15\%, 39\% and 33\% respectively). The marginal effect becomes positive in clusters with higher productivity, where a rise in $1 \%$ in the share in revenue leads to an increase of about $51 \%$ (cluster 4) and $36 \%$ (cluster 5) in the probability of remaining in the same group. The effects of economies of scale are thus weaker in the lowest productivity group. A similar effect can be observed when the number of employees is used as a proxy for economies of scale, although the coefficients in this case are lower than those of the share in the sector revenue.

Secondly, the variables associated with innovation efforts (innovation and in_wf) heighten the probability that a firm moves to a higher productivity group, or remain in such a group. Firms that introduce new products in the market are $2 \%, 5 \%$ and $4 \%$ less likely to remain in group 1 , group 2 and group 3, respectively. Inversely, firms that innovate are $6.6 \%$ and $5 \%$ more likely to remain in groups 4 and 5, respectively. In addition, firms which have a more educated workforce (study time) also tend to move to higher-productivity groups.

Thirdly, indicators of cumulative learning - length of employment in the firm and workers' years of experience-are strongly associated with a higher probability of belonging to groups 4 and 5 .

Fourthly, learning by exporting is positively related to the probability of either moving towards a group of higher productivity or remaining in a high productivity group (for those firms in groups 4 and 5) ${ }^{4}$.

\footnotetext{
${ }^{4}$ A similar result is reported by Araújo (2006), who found evidence of a positive relationship between productivity and exports.
} 
Finally, government support has a positive effect on the probability of belonging to the upper productivity strata (groups 4 and 5). This variable increases by $1.7 \%$ the probability of remaining in the group of medium-high productivity and by $1.2 \%$ the probability of remaining in the group of high productivity. In addition, government support reduces the probability of remaining in a low-productivity group (and therefore encourages the upgrading of the firm towards a higher productivity group). It cannot be deduced from these results that public support reduces $\mathrm{SH}$, since it improves the competitive position of firms located in both the low productivity groups and in the high productivity groups. In other words, it does not discriminate in favour of firms that have lost ground in the productivity race. Public financing, on the other hand, has a negative influence on the probability of moving towards groups with higher productivity levels. This result contradicts what it was expected. Firms with lower productivity tend to be smaller and less competitive, lacking the resources required for investing in technological change. They should therefore respond positively to public financing, raising innovation efforts and productivity. Although it is not clear why the response of productivity to public finance is negative, a possible explanation is that causality may run in the opposite direction, i.e., public funds keep alive firms that are in trouble and this is why their productivity levels are lower than in other firms.

In sum, all variables are significant and show the expected signs (except public financing), confirming the importance of the interaction between capabilities, leartning efforts and increasing returns in the evolution of firms' productivity and SH.

\subsection{Results of the probit model: industries by technological intensity}

Not all sectors offer the same opportunities in terms of innovation and learning. Technology-intensive sectors define more dynamic trajectories for productivity growth. A second ordered probit model was tested in order to take into account sector-specific effects in the behaviour of productivity. As in the previous model, the dependent variable is defined by the groups of firms formed on the basis of labour productivity. But these groups are now not formed with all the firms in the sample, but separated in four categories defined by their technological intensity: sectors with low, medium, medium- 
high and high technological intensity. The technological intensity of the sectors is defined in accordance with the OECD classification. Table 3 shows the codes of the different sectors at a 3-digit level of CNAE, and the number of firms that belong to each category of technological intensity. Appendix 2.2 gives the name (at a 3-digit level) of the sectors included in each of the technological categories, and the number of firms in each category.

The group of high technological intensity is formed by the industry of capital goods, electrical equipment and aircraft. It contains sectors which are crucial for the diffusion of technology and the speeding up of the innovation process (Dosi, 1990; Nelson, 2006). The group of medium-high technological intensity contains mainly durable consumer goods and intermediate goods. It also includes sectors which are intensive in economies of scale and knowledge (in the pharmaceutical and chemical industries). The group of medium-low technological intensity is formed by intermediate goods with small level of investments in $\mathrm{R} \& \mathrm{D}$, such as the petroleum refining industry ${ }^{6}$, cement and metal processing sectors. Finally, the category of low technological intensity is largely formed by sectors whose innovation process depends largely on the incorporation of technology developed in other sectors. This is the case of the textile industry, wood processing, paper and agro-industrial sectors, which are what Pavitt (1984) defined as "supplier dominated"- they absorb innovations from other parts of the technological matrix.

\footnotetext{
In Brazil the oil sector is technologically more dynamic than in other Latin American countries, investing approximately $1 \%$ of its sales in $\mathrm{R} \& \mathrm{D}$, according to PIA data. Deep-sea reserves have required Petrobras, the big state petroleum firm of Brazil, to heavily invest in engineering in order to develop more sophisticated methods of oil drilling.
} 
Table 3 - CNAE Sectors by technological intensity

\begin{tabular}{|l|l|l|}
\hline Technological intensity & Number of firms & $\begin{array}{l}\text { CNAE three-digit } \\
\text { sectors }\end{array}$ \\
\hline Low & 28625 & 151 a 160, 171 a 177, 181, \\
& 182,191 a 193, 201, 202, \\
& 211 a 214, 221 a 223, 361, \\
& $369,371,372$. \\
\hline Medium low & 231 a 234, 251, 252, 261 a \\
\hline Medium high & 13589 & $264,269,271$ a 275, 281 a \\
& & $284,288,289,351$. \\
\hline High & 10378 & 241 a 249, 291 a 299, 311 a \\
& & $316,318,319,341$ a 345, \\
& & $352,359$. \\
\hline \multirow{2}{*}{1543} & $301,302,321$ a 323, 329, \\
\hline & 331 a 335, 339, 353. \\
\hline
\end{tabular}

Source: Prepared on the basis of PINTEC data.

For each of these categories, in turn, was estimated the optimal number of labour productivity groups using the k-mean cluster methodology. Three technological categories (low-, medium-low and medium technology) were separated into five productivity groups; the high-technology category, on the other hand, comprised four productivity strata, being more homogeneous than the other categories in terms of productivity.

As can be seen in Figure 3, the results clearly indicate the existence of strong asymmetries in productivity between different technological sectors (sector matters for productivity). Asymmetries can be observed as well within sectors, i.e. between firms that belong to the same sector. 
Figure 3 - Productivity groups in sectors with different technological intensity-2008

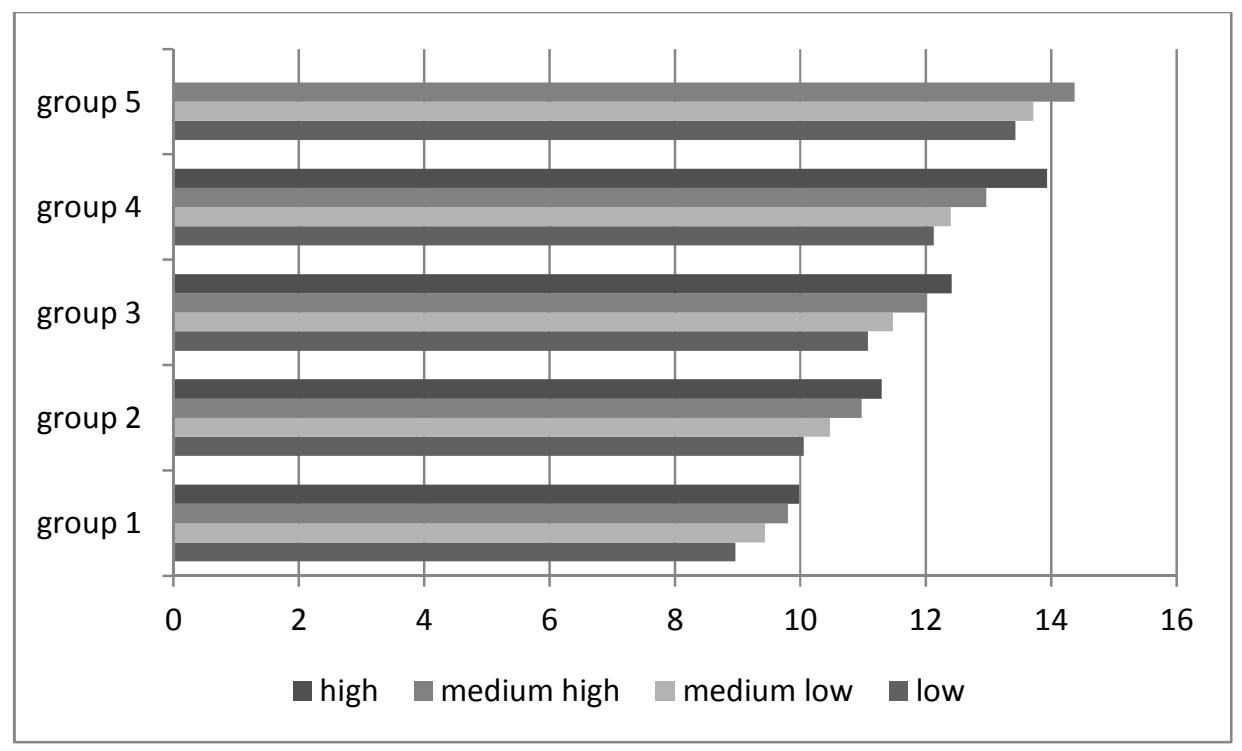

\section{Source: Prepared on the basis of PINTEC and PIA data.}

The technological intensity of the sector is related to the rates of growth of each sector. The category of medium technological intensity achieved the highest rate of growth $30 \%$ in the period), followed by the category of high-technological intensity (26\%). Categories which are less dynamic form a technological point of view attained significantly lower rates of growth (18\% for medium-low technological intensity and 13\% for low technological intensity).

Table 4 summarizes the results obtained from the ordered probit model with different categories of technological intensity. Such results confirm the findings of the previous section. Scale effects-approached by the firm's share of the total sector revenuepositively influence the probability of belonging to groups with higher productivity. For firms within the group of low technological intensity the effect is larger, and diminishes as we move towards sectors with higher technological intensity. This result validates the Schumpeterian argument which sees a circular causation between size, technological change and differences in the firms' performance (productivity, profit rate) (Dosi, 1990). On the other hand, the number of employees as a proxy for economies of scale renders ambiguous results. 
Table 4 - Results of the Ordered Probit Model in in sectors with different technological intensity

\begin{tabular}{|c|c|c|c|c|}
\hline Variable & intec_low & intec_med_low & intec_med_high & intec_high \\
\hline \multirow[t]{2}{*}{ Contract } & $-0,0001$ & 0,0002 & $-0,0001$ & 0,0002 \\
\hline & $(0,0000)$ & $(0,0000)$ & $(0,0000)$ & $(0,0000)$ \\
\hline \multirow[t]{2}{*}{ share_income } & 105,2329 & 52,9737 & 29,1569 & 10,3245 \\
\hline & $(8,3836)$ & $(7,5410)$ & $(4,1338)$ & $(5,0103)$ \\
\hline \multirow{2}{*}{$\begin{array}{c}\text { learning by } \\
\text { exporting }\end{array}$} & 0,5745 & 0,6681 & 0,5085 & 0,3804 \\
\hline & $(0,0209)$ & $(0,0316)$ & $(0,0316)$ & $(0,0743)$ \\
\hline \multirow[t]{2}{*}{ Innovates } & 0,1231 & $0,0024^{\mathrm{a}}$ & 0,2280 & $0,0397^{\mathrm{a}}$ \\
\hline & $(0,0385)$ & $(0,0495)$ & $(0,0387)$ & $(0,0826)$ \\
\hline \multirow[t]{2}{*}{ in_wf } & 0,0140 & 0,0029 & 0,0020 & $0,0013^{a}$ \\
\hline & $(0,0021)$ & $(0,0018)$ & $(0,0005)$ & $(0,0016)$ \\
\hline \multirow[t]{2}{*}{ study_time } & 0,2448 & 0,3350 & 0,4488 & 0,4883 \\
\hline & $(0,0077)$ & $(0,0112)$ & $(0,0123)$ & $(0,0343)$ \\
\hline \multirow[t]{2}{*}{ length_emp } & 0,0074 & 0,0040 & 0,0055 & $0,0007^{\mathrm{a}}$ \\
\hline & $(0,0004)$ & $(0,0006)$ & $(0,0006)$ & $(0,0016)$ \\
\hline \multirow{2}{*}{$\begin{array}{c}\text { learning by } \\
\text { doing }\end{array}$} & 0,0490 & 0,0542 & 0,0539 & $0,0152^{\mathrm{a}}$ \\
\hline & $(0,0034)$ & $(0,0049)$ & $(0,0049)$ & $(0,0119)$ \\
\hline \multirow[t]{2}{*}{ public_sup } & $-0,1783$ & $-0,1360$ & 0,1105 & 0,0822 \\
\hline & $(0,0207)$ & $(0,0299)$ & $(0,0308)$ & $(0,0072)$ \\
\hline \multirow[t]{2}{*}{ public_fin } & 0,2155 & $-0,0914$ & $-0,0616$ & $0,0007^{\mathrm{a}}$ \\
\hline & $(0,0367)$ & $(0,0533)$ & $(0,0485)$ & $(0,1194)$ \\
\hline Observations & 12704 & 6285 & 6008 & 1087 \\
\hline Lrchi $^{2}$ & 4208,56 & 2837,86 & 3300,40 & 442,99 \\
\hline
\end{tabular}

Source: Prepared on the basis of data of PINTEC, PIA, SECEX and RAIS.

${ }^{a}$ Not significant at the $5 \%$ level 
As expected, the presence of employees in innovation activities increases the likelihood that the firm moves towards or remain in groups of higher productivity. The effect of this "creative class of workers" is positive and significant for the sectors of low technological intensity and medium technological intensity, but not significant for the sectors of high technological intensity. There is no good explanation of why the effect disappears in high tech sectors. It is possible that most firms already have a large number of these innovative employees, and therefore there are no marginal effects for this variable. On the other hand, years of education have a strong influence on productivity. This influence increases with the technological intensity of the sector, suggesting that the influence of formal education is higher in the high-tech sectors-which demand more sophisticated scientific and technological skills.

Workers' cumulative learning has a favourable effect on productivity. However, in the case of this variable, its influence achieves its maximum in the sectors of medium-and medium-high technological intensity, that rely on a more informal, experience-based and trouble-shooting kind of learning.

Learning by exporting is another positive factor in the migration of firms towards groups of higher productivity. The influence of this variable is greater in sectors with lower technological intensity. Therefore, international standards and competition are particularly important as drivers of learning in lower technology sectors.

Finally, among the variables related to public incentives, government support for innovation turned out to be positive in sectors of higher technological intensity. In contrast, for the sectors of lower technological intensity, the effect is negative. Public finance has a negative influence on the groups of intermediate technology, but a positive influence on productivity in sectors with low and with high technological intensity. These last two results cast new questions about the type of public policy which is most suitable to encourage productivity growth. The response of firms to policy seems to be nonlinear, with important difference across sectors with different technological intensity. Public policies favour the upgrading in productivity in the high technology sectors, but it is less effective in sectors of intermediate technological intensity. 


\section{Conclusions and policy implications}

This paper discussed trends in productivity and structural heterogeneity $(\mathrm{SH})$ in the Brazilian manufacturing industry in the 2000s. It combined and made compatible several databases on the Brazilian manufacturing industry, innovation and micro-social data in order to build a large panel used to analyze the determinants of the evolution of productivity growth and $\mathrm{SH}$. The analysis was framed within the structuralistevolutionary theory of innovation, diffusion and technological learning. SH is important for development theory not only because it affects growth and competitiveness, but also because it boosts income inequality, which is extremely high in the case of Latin America.

The k-cluster means methodology suggests that the Brazilian firms can be optimally separated into five groups in terms of labour productivity. SH is defined as a situation in which a large share of total firms is in the lowest productivity group, and there are very large differences in labour productivity between groups and firms. The analysis confirmed that this was the case in Brazilian manufacturing, and that the distribution of productivity was not significantly altered through time-indeed, differences between firms tended to increase in the period, not to fall. $\mathrm{SH}$ is a persistent feature of the Brazilian manufacturing sector.

The forces that give rise to SH are those identified by the Schumpeterian literature as the drivers of polarization-divergent forces that concentrate innovation and learning in a few firms and sectors, while the laggards have to exit the industry-, as opposed to technological diffusion and catching up in the industrial structure-convergent forces that allow laggard firms to learn from, adapt and improve on the best practice. Increasing returns may, in principle, be counteracted by public policies that enhance the diffusion of technology. The evidence from Brazil suggests, however, that cumulativeness in innovation and learning tended to prevail over policies. From one hand, public support did encourage productivity growth, but favoured all firms, independently of the productivity group to which they belong. They therefore did not have a bias in favour of 
diffusion as compared to selection. On the other hand, public finance seems to have played a negative role in the migration of firms from the lowest productivity group towards those groups with higher labour productivity.

These results do not imply that there is no role for public policy in reducing SH. Policies may be aimed, for instance, at raising the level of education and training of workers and the number of innovative employees in the low productivity groups. These variables proved to be effective in helping the migration of firms towards groups with higher productivity. In addition, more focalized public policies (specifically directed at smaller firms or at speeding up diffusion) may produce a bias in favour of catching up (as opposed to selection), thereby curbing market concentration and the skewness in productivity. Last but not least, the sector matters for productivity growth. A form of reducing asymmetries may be fostering industrial diversification towards more dynamic sectors. A policy of diversification would open new trajectories of learning which would be more efficient in diffusing technology than trying to encourage innovation in firms located in sectors whose technological opportunities are very low.

\section{References}

Aghion, P.; Howitt, P. (1997) Endogenous growth theory, MIT Press, Cambridge, MA.

Araújo, A. (2006) "Análise empírica dos efeitos ex-post das exportações sobre a produtividade, emprego e renda das empresas brasileiras", Working Paper, IPEA.

Atkinson, A. and J. Stiglitz (1969), "A new view of technological change", Economic Journal, vol. 79, No. 315, pp. 573-57.

Cimoli, M. y Dosi, G. (1995) "Technological Paradigms, Patterns of Learning and Development: An Introductory Roadmap," Journal of Evolutionary Economics, 5(3), pages 243-68.

Cimoli, M. and Porcile, G. (2009) "Sources of Learning Paths and Technological Capabilities: An Introductory Roadmap to Development Processes", Economics of Innovation and New Technology, 18(7), pp. 675-694. 
Cimoli, M. and Porcile, G. (2011) "Learning, Technological Capabilities and Structural Dynamics", in Ocampo, J.A. and Ros, J. (2011) The Oxford Handbook of Latin American Economics, Oxford University Press.

Dosi, G. (1988), "Sources, Procedures and Microeconomic Effects of Innovation", Journal of Economic Literature, 26(3), pp. 1120-1171

Dosi, S. Lechevalier, A. Secchi (2010) "Introduction: Interfirm heterogeneity? Nature, sources and consequences for industrial dynamics Industrial And Corporate Change, 19(6), pp. 1867-1890.

Dosi, G.; Pavitt, K.; Soete, L. The economics of technical change and international trade. London: Harvester-Wheatsheaf, 1990.

ECLAC (2010), Time for Equality: Closing Gaps, Opening Trials. Santiago, ECLAC.

ECLAC (2012) Structural Change for Equality: An Integrated Approach to Development. Santiago: ECLAC.

Freeman, (1995), "The National System of Innovation in Historical Perspective", Cambridge Journal of Economics, Vol. 19, 5-24.

Furtado, C. (1969) “Teoría y política del desarrollo económico”, México.

Furtado, C. (1972) “O mito do desenvolvimento económico”São Paulo, Civilização Brasileira.

Grossman, G.; Helpman, E. (1991) Innovation and Growth in the Global Economy. Cambridgge, MIT Press.

Infante, R, y Sunkel, O. (2009) "Chile: Hacia un desarrollo inclusivo", Revista de la CEPAL, 98, abril, pp. 135-154.

Katz, (1987) J. (1987), Technology Generation in Latin American Manufacturing Industries: Theory and Case-Studies Concerning its Nature, Magnitude and Consequences, London, The Macmillan Press.

McMillan, M. and Rodrik, D. (2011) "Globalization, Structural Change and Productivity Growth”, Joint ILO-WTO paper, February.

Metcalfe (2001) "Institutions and Progress", Industrial and Corporate Change. Oxford University Press, Vol. 10, n.3, 561-86.

Nelson, R. (2006) "As fontes do crescimento econômico". Campinas, Editora da Unicamp, 2006. 
Pavitt (1984) "Sectoral patterns of technological change: towards a taxonomy and a theory", Research Policy, Vol. 13, n.6, 343-75.

Pinto, A. (1969) "Concentración del progreso técnico y de sus frutos en el desarrollo latinoamericano", em BIANCHI (ed.) América Latina. Ensayos de interpretación económica, Santiago.

Pinto, A. (1970) "Heterogeneidad estructural y modelo de desarrollo reciente de la América Latina". Inflación: raíces estructurales, México, D. F., Fondo de Cultura Económica.

Pinto, A. (1976), "Naturaleza e implicaciones de la heterogeneidad estructural de la América Latina", en El Trimestre Económico, vol. 37 (1).

Prebisch, R. (1950) "The Economic Development of Latin America and Its Principal Problems" New York: United Nations.

Prebisch, R. (1952) "Problemas teóricos y prácticos del crecimiento económico". New York: CEPAL-UN.

Rodríguez, O. (2007) “El Estructuralismo Latinoamericano”. México: Siglo XXI.

Sunkel O. (1978) "La dependencia y la heterogeneidad estructural", Trimestre Económico, Vol. 45 (1), pp.3-20. 


\section{Appendix 1}

\section{The cluster $\mathrm{k}$-means methodology}

Formally, given a set of $n$ firms in the real $d$-dimensional space $\left(R^{\mathrm{d}}\right)$ and an integer $k$, the $\mathrm{k}$-means method is a non-hierarchical technique which defines $k$ set of points that belongs to $R^{\mathrm{d}}$ which minimizes the mean square distance of each point to the centroid (mean) of the group. The method consists of, firstly, separating the elements (firms) into $k$ clusters or initial groups. Secondly, each component (firm) is allocated to the group whose centroid is the nearest. Thirdly, it is recalculated the centroid of the group that received a new element, and that of the conglomerate that lost this same element. The second step and third steps of the procedure are repeated until an optimum arrangement is achievedoptimum in the sense that no rearrangement of its components is feasible without increasing the distance of the elements with respect to the centroid.

In non-hierarchical procedures, it is necessary to specify at the beginning the number of groups to be formed, and then choose the optimal number following a certain criterion. To select the most appropriate number of groups $(k)$ in the k-means technique, Calinski and Harabasz (1974) propose an index, called index $\mathrm{CH}$, defined as follows:

$$
C H=\frac{B^{*}(n-k)}{W *(k-1)}
$$

in which $n$ is the number of points and $k$ is the number of groups. The matrix $W$ is given by:

$$
W=\sum_{i=1}^{K} \sum_{j=1}^{n_{i}}\left(X_{i j}-\bar{X}_{i}\right)^{2}
$$

$\mathrm{W}$ is the sum of squares of the distances of the points from the centre of the group to which each point belongs, $X_{i j}$ is the $j$ th point of group $i, \bar{X}_{i}$ is the centroid of the group (mean of points to the centre of the group), and $n_{i}$ is the number of points in the group $i$. The matrix B of equation (5) is obtained as follows; 


$$
\begin{aligned}
& T=\sum_{i=1}^{K} \sum_{j=1}^{n}\left(X_{i j}-\bar{X}\right)^{2} \\
& B=T-W \sum_{i=1}^{k} n_{i}\left(\bar{X}_{i}-\bar{X}\right)^{2}
\end{aligned}
$$

$T$ is the sum of the squares of the differences of each point of the entire database and the centre of the entire base, represented by $\bar{X} . B$ is the difference between $T$ and the product of $W$ (defined in (6)) times the sum of squares of the distance between the centre of the entire base and the centre of each group. To obtain the optimal number of groups in the total sample, the $\mathrm{CH}$ index is estimated for different values of $k$, and subsequently the $k$ with the greatest $\mathrm{CH}$ value is chosen. 


\section{Appendix 2}

\subsection{Definition and measurement of the variables}

\begin{tabular}{|c|c|c|c|}
\hline Variable & Definition & Unit & Source \\
\hline Contract & $\begin{array}{l}\text { Total number of employees } \\
\text { in the firm }\end{array}$ & Thousands & $\begin{array}{c}\text { Annual Report on } \\
\text { Social Data (Relação } \\
\text { anual das Informações } \\
\text { Socias, RAIS) }\end{array}$ \\
\hline $\begin{array}{l}\text { Share } \\
\text { income }\end{array}$ & $\begin{array}{l}\text { Firm's share in the total } \\
\text { income of the sector }\end{array}$ & Percentage & $\begin{array}{c}\text { Annual Industrial } \\
\text { Survey (Pesquisa } \\
\text { Industrial Anual, PIA) }\end{array}$ \\
\hline $\begin{array}{l}\text { Learning by } \\
\text { exporting }\end{array}$ & Export coefficient & $\begin{array}{l}\text { Value of exports } \\
\text { in Reales / Total } \\
\text { sales in Reales }\end{array}$ & $\begin{array}{c}\text { Trade Secretary } \\
\text { (Secretaria de } \\
\text { Comércio Exterior, } \\
\text { SECEX) }\end{array}$ \\
\hline Innovate & $\begin{array}{l}\text { Innovations of the firms in } \\
\text { new products and processes }\end{array}$ & $\begin{array}{c}\text { Dummy variable: } \\
\text { Innovations = } 1 ; \\
\text { No innovations } \\
=0\end{array}$ & $\begin{array}{c}\text { Industrial Research on } \\
\text { Technological } \\
\text { Innovation (Pesquisa } \\
\text { Industrial de Inovação } \\
\text { Tecnológica, } \\
\text { PINTEC) }\end{array}$ \\
\hline In wf & $\begin{array}{l}\text { Professional and technical } \\
\text { personnel working on } \\
\text { innovation and } \mathrm{R} \& \mathrm{D}\end{array}$ & $\begin{array}{l}\text { Percentage over } \\
\text { total employment }\end{array}$ & $\begin{array}{l}\text { Industrial Research on } \\
\text { Technological } \\
\text { Innovation (Pesquisa } \\
\text { Industrial de Inovação } \\
\text { Tecnológica, } \\
\text { PINTEC) }\end{array}$ \\
\hline Study Time & $\begin{array}{l}\text { Average years of school of } \\
\text { the workers of the firms }\end{array}$ & Years & $\begin{array}{c}\text { Annual Report on } \\
\text { Social Data (Relação } \\
\text { anual das Informações } \\
\text { Socias, RAIS) }\end{array}$ \\
\hline Length emp & $\begin{array}{l}\text { Average time of } \\
\text { employment of the workers } \\
\text { in the firm }\end{array}$ & Months & $\begin{array}{c}\text { Annual Report on } \\
\text { Social Data (Relação } \\
\text { anual das Informações } \\
\text { Socias, RAIS) }\end{array}$ \\
\hline
\end{tabular}




\begin{tabular}{|l|l|c|c|}
\hline $\begin{array}{l}\text { Learning by } \\
\text { doing }\end{array}$ & $\begin{array}{l}\text { Average time of the } \\
\text { workers in formal } \\
\text { employment (in the firm or } \\
\text { in other firms) }\end{array}$ & Months & $\begin{array}{c}\text { Annual Report on } \\
\text { Social Data (Relação } \\
\text { anual das Informações } \\
\text { Socias, RAIS) }\end{array}$ \\
\hline Public sup & $\begin{array}{l}\text { Support of the government } \\
\text { to research in the sector } \\
\text { (tax incentives, venture } \\
\text { capital and grants and } \\
\text { support for hiring } \\
\text { researchers and scientific } \\
\text { personnel) }\end{array}$ & $\begin{array}{c}\text { Receives support } \\
=1 \text { Receives no } \\
\text { support =0 }\end{array}$ & $\begin{array}{c}\text { Industrial de Inovação } \\
\text { Tecnológica, } \\
\text { PINTEC) }\end{array}$ \\
\hline Public Fin & $\begin{array}{l}\text { Public finance of R\&D } \\
\text { (financing of R\&D and / or } \\
\text { the purchase of equipment } \\
\text { required for R\&D } \\
\text { activities) }\end{array}$ & $\begin{array}{c}\text { Dummy variable: } \\
\text { Receives finance } \\
=1 ;\end{array}$ & $\begin{array}{c}\text { Industrial Research on } \\
\text { Technological } \\
\text { Innovation (Pesquisa } \\
\text { Industrial de Inovação } \\
\text { Tecnológica, } \\
\text { PINTEC) }\end{array}$ \\
\hline
\end{tabular}


2.2. Sectors: National Classification of Economic Activities2.0

\begin{tabular}{|c|c|}
\hline CNAE 2.0 - Section C: manufacturing Industry & $\begin{array}{c}\begin{array}{c}\text { Number of } \\
\text { firms }\end{array} \\
\end{array}$ \\
\hline DIVISION 10- Food & 1251 \\
\hline DIVISION 11 - Beverages & 179 \\
\hline DIVISION 12 - Tobacco & 16 \\
\hline DIVISION 13 - Textiles & 565 \\
\hline DIVISION 14 - garment and Accessories & 898 \\
\hline DIVISION 15- Leather products & 513 \\
\hline DIVISION 16 - Wood products & 246 \\
\hline DIVISION 17 - Pulp, cellulose and paper products & 272 \\
\hline DIVISION 18 - Printing & 127 \\
\hline $\begin{array}{l}\text { DIVISION } 19 \text { Oil derivatives and combustibles, including bio- } \\
\text { combustibles }\end{array}$ & 85 \\
\hline DIVISION 20 - Chemical products & 606 \\
\hline DIVISION 21 - Pharma & 159 \\
\hline DIVISION 22 - Plastic and rubber goods & 896 \\
\hline DIVISION 23-Nonmetallic minerals & 869 \\
\hline DIVISION 24 - Metalurgy & 334 \\
\hline DIVISION 25 - Metal products, except machinery and equipment & 886 \\
\hline DIVISION 26 - Electronics and Informatic equipment & 228 \\
\hline DIVISION 27 - Electric machinery and equipment & 323 \\
\hline DIVISION 28 - machinery and equipment & 770 \\
\hline DIVISION 29 - Automobiles & 483 \\
\hline DIVISION 30 - Other transport equipment & 64 \\
\hline DIVISION 31 - Furniture & 491 \\
\hline DIVISION 32 - Miscelaneous products & 270 \\
\hline $\begin{array}{l}\text { DIVISION } 33 \text { - Reparation and installation of machinery and } \\
\text { equipment }\end{array}$ & 39 \\
\hline
\end{tabular}

Source: CONCLA, 2007. 